\title{
A study on the adequacy of dietary intake of macro nutrients for pregnant mothers in Kalutara district
}

\author{
By \\ Gallage Rasika Pushpa Kumara Perera
}

M.Sc.

2015

The thesis is submitted in partial fulfillment of the M.Sc. program in Food Science and Technology at University of Sri Jayawardenepura, Gangodawila, Nugegoda, Sri Lanka in 2015 


\section{DECLARATION}

The work described in this thesis was carried out by me at the University of Sri Jayewardenepura under the supervision of Dr. (Mrs.) Indira Wickramasinghe, Senior Lecturer, Department of Food Science and Technology, Faculty of Applied Sciences, University of Sri Jayewardenepura. Report on this thesis has been not been submitted in whole or in part to any other institution for another degree/diploma.

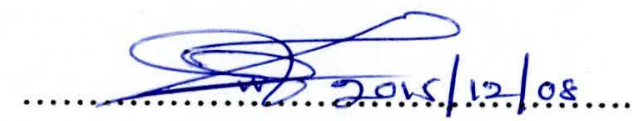

Gallage Rasika Pushpa Kumara Perera 
We certify that the above statement made by the candidate is true and this thesis is suitable for submission.

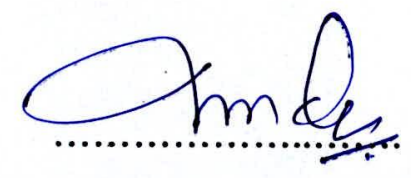

Supervision: Dr. (Mrs.) Indira Wickramasinghe,

Senior Lecturer,

Department of Food Science and Technology,

Faculty of Applied Sciences,

University of Sri Jayewardenepura
$8 / 12 / 2015$

Date 


\section{TABLE OF CONTENT}

Table of content $\quad$ i

List of figures vii

List of tables $\quad x$

Acknowledgment $\quad$ xii

Abstract xiii

$\begin{array}{lr}\text { CHAPTER 1 - INTRODUCTION } & 1\end{array}$

1.1 Objectives 2

CHAPTER 2 - LITERATURE REVIEW

2.1 Nutrition recommendations for women $\quad 4$

2.2 Pregnancy and nutrition 5

$\begin{array}{ll}2.3 \text { Weight gain during pregnancy } & 7\end{array}$

2.4 Nutritional Recommendations for Women during pregnancy 8

2.4.1 Energy intake $\quad 8$

$\begin{array}{ll}\text { 2.4.2 Protein intake } & 10\end{array}$

2.4.3 Lipids and fats intake $\quad 11$

2.4.4 Essential fatty acids intake $\quad 12$

$\begin{array}{lr}\text { 2.4.5 Fiber intake } & 14\end{array}$

$\begin{array}{ll}\text { 2.4.6 Carbohydrate intake } & 14\end{array}$

$\begin{array}{ll}2.4 .7 \text { Vitamin “A” intake } & 15\end{array}$ 
2.4.8 Calcium intake

2.4.9 Vitamin " $B$ " intake

2.4.10 Vitamin " $\mathrm{B}_{12}$ " intake 17

2.4.11 Folate intake

2.4.12 Iron intake 19

2.5 Critical periods of nutrient intake 21

2.6 Common problems associated with pregnancy 22

2.6.1 Nausea and vomiting of pregnancy and food aversions and cravings 22

2.6.1.1 Nausea and vomiting 23

2.6.1.2 Cravings and aversions 25

2.6.2 Reflux 27

2.6.3 Pica 28

2.6.4 Preeclampsia 28

2.6.5 Gestational diabetes 30

2.7 The interaction of life-style and pregnancy 32

2.7.1 Physical activity 33

2.7.2 Food Safety 34

2.7.2.1 Swordfish, tilefish, king mackerel, and shark. 36

2.7.2.2 Raw sprouts. 36

2.7.2.3 Unpasteurized or untreated juice. 36

2.7.2.4 Alcohol 36

2.7.2.5 Illegal drug use 38

2.7.2.6 Cigarette (Smoking) 38 
3.2 Data collection $\quad 41$

$\begin{array}{ll}\text { 3.2.1 Personal information } & 41\end{array}$

3.2.2 Anthropometric information 43

3.2.3 Dietary information $\quad 44$

3.3 Tabulation of information $\quad 44$

3.3.1 Tabulation of information gathered 44

3.3.2 Tabulation of information on dietary recommendation 45

$\begin{array}{ll}\text { 3.3.2.1 Weight gain } & 45\end{array}$

$\begin{array}{ll}\text { 3.3.2.2 Energy intake } & 46\end{array}$

3.3.2.3 Protein intake 46

$\begin{array}{ll}\text { 3.3.2.4 Carbohydrate intake } & 47\end{array}$

$\begin{array}{ll}\text { 3.3.2.5 Fat intake } & 47\end{array}$

$\begin{array}{ll}\text { 3.3.2.6 Mineral and vitamin intake } & 47\end{array}$

$\begin{array}{lll}3.4 & \text { Data analysis } & 47\end{array}$

CHAPTER 4 - RESULTS AND DISCUSSIONS

$\begin{array}{ll}\text { 4.1 Statistics of general information } & 49\end{array}$

4.1.1 Statistics of age of the individuals $\quad 50$

4.1.2 Statistics of number of living children own by the individuals 51 
4.1.3 Statistics of the age of youngest child of individuals in the sample

4.1.4 Statistics of the race of individuals in the sample

4.1.5 Statistics of the religion of individuals in the sample

4.1.6 Statistics of the civil status of individuals in the sample

4.1.7 Statistics of the education level of individuals in the sample

4.1.8 Statistics of the education level of husbands' in the sample

4.1.9 Statistics of the profession of individuals in the sample

4.1.10 Statistics of the profession of the individuals' husbands in the sample

4.1.11 Results on the family income of individuals in the sample

4.2 Statistics of the anthropometric information of individuals in the sample

4.3 Statistics of the trimester spending by individuals in the sample

4.4 Statistics of weight gain percentage of individuals in the sample

4.5 Statistics of dietary information of individuals in the sample

4.5.1 Statistics of energy intake percentage of individuals in the sample

4.5.2 Statistics of protein intake percentage of individuals in the sample

4.5.3 Statistics of carbohydrate intake percentage of individuals in the sample 75

4.5.4 Results on fat intake percentage of individuals in the sample

4.7 Determination of adequacy of "energy intake"

4.8.1 Determination of adequacy of "protein intake"

4.8.2 Determination of adequacy of "carbohydrate intake" 
4.9 Determination of correlation between percentages of weight gain and dietary nutrient intake.

4.10 Determination of correlation between percentages of dietary energy intake and dietary macro nutrient intake.

4.11 Determination of deference between means of percentages of weight gain, energy intake, protein intake, carbohydrate intake and fat intake in three trimesters.

4.11.1 Determination of deference between means of percentages of weight gain in three trimesters.

4.11.2 Determination of deference between means of percentages of energy intake per day in three trimesters.

4.11.3 Determination of deference between means of percentages of protein intake per day in three trimesters.

4.11.4 Determination of deference between means of percentages of carbohydrate intake per day in three trimesters.

4.11.5 Determination of deference between means of percentages of fat intake per day in three trimesters. 


\section{APPENDICES}

Appendix I - Table of food composition with unit amounts and food code

Appendix II -Questioner 


\section{LIST OF TABLES}

Table 2.1: Analysis of weight gain $(\mathrm{g})$ in pregnancy

Table 3.1 Extra energy requirement of the pregnant mother in each trimester

Table 4.1 Statistics of age distribution of the sample

Table 4.2: Statistics of the distribution of number of living children own by individuals 51

Table 4.3: Statistics of the distribution of age of youngest child of individuals

Table 4.4: Statistics of the race distribution of the sample

Table 4.5: Statistics of the religion of individuals of the sample

Table 4.6: Statistics of the civil status of individuals of the sample

Table 4.7: Statistics of the education level of individuals of the sample

Table 4.8: Statistics education levels of husbands' of the sample

Table 4.9: Statistics of the profession of individuals of the sample

Table 4.10: Statistics of the profession of the individuals' husbands

Table 4.11: Statistics of the distribution family income level sample

Table 4.12: Family income level and their values

Table 4.13: Statistics of the distribution of Anthropometric information of individuals 65

Table 4.14: Statistics of the distribution of trimester spending by individuals

Table 4.15: Statistics of the distribution of weight gain percentage of individuals

Table 4.16: Statistics of the distribution of energy intake percentage of individuals

Table 4.17: Statistics of the distribution of protein intake percentage of individuals

Table 4.18: Statistics of the distribution of carbohydrate intake percentage 
Table 4.19: Statistics of the distribution of fat intake percentage of individuals

Table 4.20: Paired samples statistics (Required weight gain- Actual weight gain)

Table 4.21: Paired samples correlations (Required weight gain- Actual weight gain) $\quad 80$

Table 4.22: Paired samples test (Required weight gain- Actual weight gain) $\quad 80$

Table 4.23: Paired samples statistics (Required energy intake- Actual energy intake) 81

Table 4.24: Paired samples correlations (Required energy intake- Actual energy intake) 81

Table 4.25: Paired samples test (Required energy intake- Actual energy intake) $\quad 81$

Table 4.26: Paired samples statistics (Required protein intake- Actual protein intake) $\quad 82$

Table 4.27: Paired samples correlations (Required - Actual protein intake) 83

Table 4.28: Paired samples test (Required protein intake- Actual protein intake) $\quad 83$

Table 4.29: Paired samples statistics (Required - Actual carbohydrate intake) $\quad 84$

Table 4.30: Paired samples correlations (Required carbohydrate intake- Actual carbohydrate intake)

Table 4.31: Paired samples test (Required carbohydrate intake- Actual carbohydrate intake)

Table 4.32: Paired samples statistics (Required fat intake- Actual fat intake) $\quad 86$

Table 4.33: Paired samples correlations (Required fat intake- Actual fat intake) $\quad 86$

Table 4.34: Paired samples test (Required fat intake- Actual fat intake) 86

Table 4.35: Correlations (Between weight gain and dietary nutrient intakes) $\quad 88$

Table 4.36: Descriptive (Means of percentages of weight gain) 90

Table 4.37: ANOVA (Means of percentages of weight gain) 91

Table 4.38: Multiple comparisons (Between means of percentages of weight gain) 91

Table 4.39: Descriptive (Means of percentages of energy intake) 93 
Table 4.40: ANOVA (Means of percentages of energy intake)

Table 4.41: Multiple comparisons (Between means of percentages of weight gain) 94

Table 4.42: Descriptive (Means of percentages of protein intake) 96

Table 4.43: ANOVA (Means of percentages of protein intake) 96

Table 4.44: Descriptive (Means of percentages of carbohydrate intake) 98

Table 4.45: ANOVA (Means of percentages of carbohydrate intake) 98

Table 4.46: Descriptive (Means of percentages of fat intake) 100

Table 4.47: ANOVA (Means of percentages of fat intake) 100

Table 4.48: Multiple comparisons (Between means of percentages of fat intake) $\quad 101$ 


\section{LIST OF FIGURES}

Figure 4.1 Graphical expression of the age of individuals in the sample 51

Figure 4.2: Graphical expression of age of youngest child of individuals 53

Figure 4.3: Graphical expression of the race of individuals in the sample $\quad 54$

Figure 4.4: Graphical expression of the religion of individuals in the sample 55

Figure 4.5: Graphical expression of the education level of individuals in the sample $\quad 57$

Figure 4.6: Graphical expression of the educational level of husbands' in the sample 59

Figure 4.7: Graphical expression of the profession of individuals in the sample $\quad 61$

Figure 4.8: Graphical expression of the profession of the husbands' in the sample $\quad 62$

Figure 4.9: Graphical expression of the family income levels in the sample 64

Figure 4.10: Graphical expression of height of individuals in the sample 67

Figure 4.11: Graphical expression of the weight at the first clinic of individuals $\quad 67$

Figure 4.12: Graphical expression of the BMI at first clinic of individuals $\quad 68$

Figure 4.13: Graphical expression of trimester spending by individuals $\quad 69$

Figure 4.14: Graphical expression of weight gain percentage of individuals $\quad 71$

Figure 4.15: Graphical expression of energy intake percentage of individuals $\quad 73$

Figure 4.16: Graphical expression of protein intake percentage individuals $\quad 75$

Figure 4.17: Graphical expression of carbohydrate intake percentage of individuals $\quad 77$

Figure 4.18: Graphical expression of fat intake percentage of individuals in the sample 79

Figure 4.19: Graphical expression between mean percentages of the weight gain in three trimesters. 
Figure 4.20: Graphical expression between mean percentages of the energy intake in three trimesters.

Figure 4.21: Graphical expression between mean percentages of the protein intake in three trimesters.

Figure 4.22: Graphical expression between mean percentages of the carbohydrate intake in three trimesters.

Figure 4.23: Graphical expression between mean percentages of the energy intake in three trimesters. 


\section{ACKNOWLEDGMENT}

I wish to express my sincere gratitude to Dr. (Mrs.) Indira Wickramasinghe Senior

Lecturer, Department of Food Science and Technology, Faculty of Applied Sciences, University of Sri Jayewardenepura, for her valuable guidance given to me.

I would like to acknowledge Dr. (Mr.) Jagath Wansapala, Head of Department, Department of Food Science and Technology, Faculty of Applied Sciences, University of Sri Jayewardenepura

I wish further to express my sincere gratitude to Dr. (Mr.) Padmal De Silva, National Institute of Health Science, Kaluthara for his valuable guidance given to me.

I would also like to acknowledge the devotion of Dr. (Mrs.) Samantha Ramachandra, National Institute of Health Science, Kaluthara

I would like to acknowledge (Mr.) Isuru Rathnayaka, Lecturer, Department of Stat, University of Sri Jayewardenepura

I would also like to acknowledge all other academic and non-academic staff members of the University of Sri Jayewardenepura, who help me in various ways.

I should acknowledge individuals and staff members of National Institute of Health Science, Kaluthara who help to gather information to the experiment.

I'm sincerely grateful to my family members who devoted themselves for me always in this regard. 


\begin{abstract}
The experiment was carried out based on 13 "Medical Officer of Health" (MOH) areas in Kalutara district to find the adequacy of the dietary intake of macro nutrient together with weight gain and energy intake during pregnancy. A questioner was distributed among pregnant mothers to collect data trough clinical sessions conducted by the midwifery officers in the area. Random sampling of questioners was done to tabulate data. One hundred twenty two individuals were taken in to account to analyze the tabulated data. General information and the dietary information were presented separately in tables and graphs. Weight gain, energy intake, protein intake, carbohydrate intake and fat intake were compared with their recommendations to evaluate the adequacy. Paired t test was conduct to evaluate the adequacy of the parameters using the software of "Statistical Program for Social Science" (SPSS). The same parameters were calculated as the percentages to the required values for the purpose of expressing the statistics. The percentages were compared among three trimesters of the pregnancy. One way "Analysis of variance" (ANOVA) test was conducted for the purpose comparison using SPSS software.
\end{abstract}

As findings, the actual dietary intake of macro nutrients of protein and carbohydrate were found as higher than the required levels. The actual energy intake and fat intake were found as in required level. But the weight gain was found as lower than the recommendations significantly. As an extra finding to the experiment, it was suggested that the evaluation of weight gain cannot be evaluated correlating with the dietary nutrients. There should be further experiment to find the reasons for lower weight gain in pregnant mothers in Kalutara district. 